ROCZNIKI FILOZOFICZNE

Volume LXIX, issue 3-2021

DOI: https://doi.org/10.18290/rf21693-13

MAREK PEPLIŃSKI

\title{
THE HIDDENNESS ARGUMENT AND THE GROUND OF ITS SOUNDNESS
}

\section{GENERAL COMMENTS ON HOW TO APPROACH THE NATURE OF GOD AND ITS IMPACT ON THE ACCURACY OF JOHN SCHELLENBERG'S ARGUMENT}

John Schellenberg's formulation of the argument from Divine hiddenness and his defense of this reasoning undoubtedly stimulate a discussion on the argument itself and various related issues. Investigations concerning the value of this argumentation inspire philosophical thinking in such matters as the knowledge of God, His existence, and His nature. They raise issues of the type and nature of possible ways of realizing personal relationships between people and God, including friendship. It is impossible not to notice that the discussion is also based on some pre-assumptions about the great traditional area of inquiry about understanding God and His plans for creatures. It is also about the possibility of using the experience of relations between finite personal beings, which are people, and the knowledge resulting from this experience for the interpretation of the personally understood God. The latter is not equivalent to the God of personalistic theism. ${ }^{1}$

Marek Pepliński, Assistant Professor at the Institute of Philosophy, University of Gdansk; correspondence address: ul. Jana Bażyńskiego 4, 80-309 Gdańsk, Poland; e-mail: marek.peplinski@ug.edu.pl; ORCID: https://orcid.org/0000-0002-5941-3374.

${ }^{1}$ See Daniel Howard-Snyder and Paul K. Moser (eds.), Divine Hiddenness. New Essays (Cambridge: CUP, 2002); Adam GrEEN and Eleonore STUMP (eds.), Hidden Divinity and Religious Belief: New Perspectives (Cambridge: CUP, 2016); Veronika WeIDner, Divine Hiddenness (Cambridge: CUP, 2021); Marek Dobrzeniecki, Ukrytość $i$ Wcielenie. Teistyczna odpowiedź na argument Johna L. Schellenberga za nieistnieniem Boga (Kraków: WAM, 2020); DOBRZENIECKI, "Argument z ukrycia. Obecny stan debaty," Przegląd Filozoficzny 28, no. 1 (2019): 17-32. 
In the article, I will refer to the argument from hiddenness as presented in the book The Hiddenness Argument ${ }^{2}$ and the philosophical views expressed there that constitute the context for understanding this argument. When examining the value of this argument, you can turn your attention to three things. First, it is possible to check whether the premises of the argument are true and convincingly justified. Second, one may wonder whether the premises and the conclusion are so related that the conclusion can be derived from the premises. This is, in part, a matter of the formal properties of a given reasoning. However, these are not matters independent of the content of the premises. As it turns out, especially in the initial steps of Schellenberg's reasoning, these matters combine unfavorably for the argument in premises (1)-(3). In my opinion, assuming a particular interpretation of the way the argument works, it also takes place in premise (6): "If no perfectly loving God exists, then God does not exist." It seems that to attain the deductive form of his reasoning and the related correctness of his inference, the author adopts premises whose truth is questionable. Third, one can consider the broader philosophical perspective from which the argument grows, the function of the argument, and the methodology of this part of the philosophy of religion. I will present my views on all three points below. I will discuss the issue of the philosophical perspective and the function of the argument at the end. There is problem with the anthropomorphism in Schellenberg's philosophy of religion and its significance for the conclusiveness of his argument. In the end, I will present a way of using the argument in a way that is not entirely unintended by its author but also in a way that does not deviate entirely from his goals.

As already mentioned, I am examining the argument presented by Schellenberg in his book for a more general audience. This argument goes as follows:

(1) If a perfectly loving God exists, then there exists a God who is always open to a personal relationship with any finite person.

(2) If there exists a God who is always open to a personal relationship with any finite person, then no finite person is ever nonresistantly in a state of nonbelief in relation to the proposition that God exists.

2 J. L. Schellenberg, The Hiddenness Argument: Philosophy's New Challenge to Belief in God (Oxford: OUP, 2015). The Polish translation of Schellenberg's book was published in 2019 as Argument $z$ ukrytości. Nowe wyzwanie filozofii dla wiary w Boga. It was translated by Ryszard Mordarski, who wrote an extensive introduction titled "Argument z ukrytości Boga Johna L. Schellenberga"; see J. L. Schellenberg, Argument z ukrytości (Bydgoszcz: Wydawnictwo Uniwersytetu Kazimierza Wielkiego), 9-35. 
(3) If a perfectly loving God exists, then no finite person is ever nonresistantly in a state of nonbelief in relation to the proposition that God exists (from 1 and 2).

(4) Some finite persons are or have been nonresistantly in a state of nonbelief in relation to the proposition that God exists.

(5) No perfectly loving God exists (from 3 and 4).

(6) If no perfectly loving God exists, then God does not exist.

(7) God does not exist (from 5 and 6). ${ }^{3}$

The argument is preceded in Schellenberg's book with the scheme of the formal type of reasoning under which this reasoning falls. This scheme clearly shows that the discussed argument is formally correct. Schellenberg wants to reach conclusion 5: "No perfectly loving God exists." For that purpose, he must guarantee the recognition of the three conditional propositions establishing a relationship of some kind between the essential attributes of God's nature, so to speak, of each God (a God and every God) and between a particular fact in the world. The status of the latter relationship is not easy to determine.

Similarly, Schellenberg does not explain where the relationships between states of affairs being correlates of sentences appearing as antecedents and consequents in (1)-(3) come from. Indeed, if the argument is to work, the fact of hiddenness should be understood by us as impossible if God existed. The nature of this impossibility, so to speak, its mechanism, is not entirely clear. For the argument to work, the contradiction between a particular fact and the essential nature of God (the constant content of the idea of the nature of God) must be recognized, and it must, of course, be confirmed that such a fact that is inconsistent with God's existence takes place.

Moreover, the relationship between God's perfect love and His openness to a personal relationship with any finite person must be necessary, and it must be an object of human knowledge. Otherwise, we have no rational, philosophical grounds for accepting the truth of the first three propositions. In such a case, their approval becomes a matter of mere opinion. In my view, this is the actual state of affairs. The arguments in the paper show that it is not necessary to acknowledge the individual steps of Schellenberg's supporting reasoning and to accept premises (1) and (2). Regardless of the last case, however, it should be remembered that the premises of Schellenberg's argument, if they are to be acknowledged, cannot be accidentally true because that would mean that they may be false. Therefore, whether their necessity is a de re or de dicto necessity,

\footnotetext{
${ }^{3}$ SCHELlenderg, The Hiddenness Argument, 103.
} 
they must be accepted as sure, stating that such dependencies cannot differ from Schellenberg's views. I argue that the author has not shown this, only showing in some cases the probability of their truth. The mere assumption that they are probable is based on the adoption of many debatable assumptions. The author himself many times assesses some sentence as obvious, evident or self-evident. ${ }^{4}$ But such declarations do not serve as a justification, especially when it is possible to construct possible situations that Schellenberg simply excludes either declaratively or by applying the unjustified assumption that omnipotent, perfect love will not create a world with such situations.

The very formal structure of Schellenberg's argument is not controversial. But what about the truth of his premises? Let us note first that in philosophical research, in philosophical disputes, it is the value of premises that gives rise to the most significant disputes. It is sporadic that they are obvious. This is because of the nature of philosophical arguments. It stems from the fact that they usually do not concern evident or plain matters, but what is not obvious, hidden. To use more poetic language, they concern what is hidden behind the veil of objects, phenomena, events, or processes given to us. Extracting the truth available requires the effort of reason, the effort of reasoning, the cooperation of intellects, intuition, sensitivity, and ingenuity of many people. It is also done by confronting your understanding with that of other people and their arguments. And so - to some extent - the circle is closed. I am not saying that this is the case with every bit of philosophy. But it is so with most metaphysical and ontological inquiries. On the results of such inquiries, whether attained or merely assumed, are dependent inquiries in the field of philosophy of religion.

Let us, then, return to the general issue of the value of premises used in Schellenberg's reasoning. Premises are not simply material signs but are propositional phrases endowed with an objective, propositional sense. The vital issue is the meaning of the terms that make up that sense. The question of the meaning of the premises leads us to the meaning of the term "God" used. It also leads to the question of the meanings or semiotic functions of other terms with which the argument tries to grasp or describe God. It is about both the alleged aspects of His nature and the possible ways of His action/non-action concerning human persons. In the case of hiddenness, the argument concerns possible actions aimed at achieving knowledge of God and preventing the appearance of a Nonresistant Nonbelief. Speaking somewhat technically, we ask about the meaning of the terms intended to grasp Him in His inner nature and His dynamic

\footnotetext{
${ }^{4}$ Ibid., e.g., 31, 41, 43, 71, 111.
} 
relationship to the created world. The understanding of the term openness in relation to relationships between people is also controversial in some cases.

\section{DOUBTS ABOUT THE EXISTENCE OF EASY KNOWLEDGE OF GOD'S NATURE (ESPECIALLY IF HE DOES NOT EXIST)}

Consider a model of a reality in which God exists that includes a world like the one we live in. How would human beings get to know God, know His existence, and know His nature? This knowledge would allow us to make inferences about His actions about the world, including actions concerning people. Would the effects of these presumed actions appear to us as common facts of some kind or as standard features of the world? This concerns facts such as divine hiddenness, in their neutral sense, and in, all things considered, theistic or atheistic meaning. This question is critical. It is also perfectly valid. Especially if the existence of God is not (does not have to be) obvious to us, ${ }^{5}$ the answer that suggests itself to a researcher of religion is this: people derive their knowledge about God, or at least what they treat as knowledge about God, primarily from their religion. Moreover, there is no philosophical view of God that is not made in the context of some religious tradition, and that does not derive its concepts or pre-understandings from it. This is significant because Schellenberg insists that a philosopher should distance himself from theological concepts when examining an argument.

When a philosopher encounters an argument intended to refer to God (since this term is derived from religion), the question arises from which religion the idea derives and from which God, whose religion the argument is to apply to. To put it differently: which God is it about and through the prism of whose conception? There are polytheistic religions and there are monotheistic ones. The notion of God in the three great monotheisms, Christianity, Judaism, and Islam, is not identical. There are also religions that do not recognize the existence of a single and only one God (with an upper-case G). It is true of Buddhism, just as it is true of polytheistic Hinduism. ${ }^{6}$

\footnotetext{
${ }^{5}$ One must distinguish between the obviousness to different types of knowing subjects. The existence of God is undoubtedly evident to Himself, but it is not immediately evident to human beings.

${ }^{6}$ The term 'god' is not identical to the term 'God' and their semiotic functions differ. Cf. Józef Herbut, "Z syntaktycznej problematyki języka religijnego," in Józef Herbut, Artykuly i szkice. $Z$ metodologii $i$ teorii metafizyki, filozoficznej analizy języka religii oraz etyki i metaetyki (Opole: Wydział Teologiczny Uniwersytetu Opolskiego, 2008), 241-43. See also Joseph M. BocHEŃSKI, The logic of religion (New York: New York University Press, 1965).
} 
As He has traditionally been understood, God is not a thing among other things, whether $\mathrm{He}$ exists or not. $\mathrm{He}$ is not an object in the world. $\mathrm{He}$ is not something of the kind that we recognize in the direct empirical perception of the world. Most people seem to derive the concepts by which they grasp God and their first judgments about Him in the context of the religions they follow or their parents or guardians do. If someone comes from a secular environment, then they derive this concept by acquainting themselves, to some extent, with other people whose religion they do not profess. The concept of God is a religious concept. It is part of a specific religion, as opposed to God himself understood as being. This is true whether God exists or not. Thus, explaining why someone has such concepts and beliefs about God most often is an explanation that depends on pointing to specific social and personal facts. It involves a person's various relationships to a religious community teaching their religion. They are related to the read Holy Texts as well as religious and theological books she read, meetings with other people, events in which she participated, stories, testimonies she heard. Sometimes this includes the anti-testimony of one or another adherent of a given religion. ${ }^{7}$ All these matters can then be the subject of reasoning, attempting to sift right concepts and true sentences away from inaccurate phrases and false opinions.

The problem is more profound than that. Even if the fact that the context of the discourse of the philosophy of religion is a particular religious tradition narrows the scope of possible understanding of God and constitutes a step towards identifying the denotation of the term God, within a given religious tradition, there are different ways of understanding the referred God. It is undoubtedly the case in Christian theology. And it is not only about the differences in the ways of understanding God in the tradition of Catholic, Orthodox, or Reformed thought. Such differences also occur within, for example, Catholicism itself, where God is understood differently by the Thomistic tradition, which emphasizes the rationality of God's nature, and the Franciscan tradition, which emphasizes divine freedom. ${ }^{8}$

\footnotetext{
${ }^{7}$ Philosophers, members of the academic community of people with similar interests, a similar way of thinking, and living in the world, usually consider essential what can be learned about God based on reasoning and various rational insights. It really is a fundamental issue for philosophy, whose task, contrary to the metaphilosophical opinion popular among analytic philosophers, is to justify and interpret what we already know and discover new things by explaining and expanding the scope of knowledge available to us. However, for the formation of the first critical opinions about God, religion, the ultimate reality, sometimes accurate, sometimes not, contacts with people of religion are of great importance. Religions have a social dimension here, too.

${ }^{8}$ A good example is the influence of different models of God's freedom on the understanding of human morality. A widely known book by Pinckaers explains it in depth; see Servais-Théodore
} 
One might think that these are irrelevant to the issue at hand. This is not the case, however. Schellenberg's inquiries about God's nature, His love, or openness lie on the same level-the level of human interpretation of the (alleged, presumed) Being of God. So which God's non-existence does Schellenberg want to demonstrate? In other words, in what concept (model) of God does Schellenberg work? The answer to this question is relevant in two ways. First of all, in our assessment of what his argumentation de facto suggests with its premises, statements, and supporting reasoning. This, in turn, is important for the reader's consent or refusal of the proposed premises, and acceptance of their value.

Schellenberg conducts the discussion as if things were obvious. It starts with God and it should be clear what is being said. In fact, nothing is evident here, and many things are unclear and out of focus. Second, suppose we were to agree that the argument makes it possible to reject the existence of a particular Being. In that case, the question arises which Being is thus excluded, and according to which conception, and which Being (given other accounts) not. Even if there are ways of relating to God intellectually, which in some cases do not use a description of the divine nature, recognizing or denying the existence of one or another God requires the use of some description and a corresponding understanding of God. We obtain the results by reasoning about such a God; the divine nature determined by such-and-such a description, concept, or conditional need not automatically apply to God understood differently. The differences between them may be subtle enough that an argument pertinent to God-designated by concept ${ }^{1}$ misses when it comes to God-designated by the concept ${ }^{2}$. Schellenberg seems to realize this, and therefore he will treat his argument so that it is about all God, or in other words, that it is about every God and the conclusion is that no God exists. All the more so, for such a robust application, his argument should provide an appropriate justification. A careful examination of the entire logic of his argument contained in the book reveals numerous partial and insufficient justifications for its essential claims.

It must be remembered that depending on the specific concept that we are dealing with of the Divine Being, His nature, attributes, goals, and ways of acting we are dealing with, we will either agree to the probability of some effects of His actions in the-world-of such-God or not. This is irrespective of whether the context is an argument for God's existence, an argument against

PINCKAERS, Les sources de la morale chrétienne. Sa méthode, son contenu, son histoire (Fribourg: Editions Universitaires, 1993); English translation: The Sources of Christian Ethics, trans. Mary T. Noble (Washington, DC: Catholic University of America Press, 1995). 
His existence, or an argument that assigns specific attributes to God and tries to deduce others from them. ${ }^{9}$ We should emphasize here that all these matters are binding and logically independent of the resolution of the question of whether thus understood God exists and whether there is any God of religion at all. Nor are these claims based on any religion being recognized as revealed or true. They may be heuristically inspired by various theological statements but do not assume their truth. These are the results of an a priori reflection on the nature of the relationship of human culture and alleged knowledge of the reality presupposed, assumed, and implied by that culture. They also concern religion and the conditions of possible ways of getting to know the objects that the followers of different religions refer to. They concern possible ways of knowing the existence or non-existence of such objects, natures, and actions. They determine the conditions for the occurrence of a given type of cognition and its value, including certainty/uncertainty. Knowledge of the methods of practicing God's ontology and metaphysics is primarily assumed.

\section{THEISM REJECTS ANTHROPOMORPHISM IN REASONING AND LANGUAGE ABOUT GOD}

Since Schellenberg begins with what he views as evident matters concerning the concept of the God of theism, it is also worth turning to these concepts for us. It is a fact that the three great theistic religions, when describing God, emphasize His uniqueness in comparison to other beings, which are referred to as creatures. Contrary to Schellenberg's suggestions, this uniqueness does not lie in His distance or inaccessibility. ${ }^{10}$ Without going into complicated metaphysical inquiries about God's creation and action towards creatures, let us note that theistic religions claim that God is both immanent and transcendent to the world he created. He is to be present in it as the Creator, the Cause of everything, and the First or Final Cause. He is to be the co-cause of its operation and its effects, and as the Omniscient, He is to know His creation better than it knows itself. As Almighty Providence, he is to look after the welfare of creatures. At the same time, precisely as the Uncreated Cause, as the Giver of being and life, as the Omni-God, it surpasses the world beings in its existence in a way that is incomprehensible to beings with our limited ability

\footnotetext{
${ }^{9}$ In the analytical philosophy of religion, especially in analytical philosophical theology there are many disputes concerning, for example, the relation of the attributes of knowledge or God's power to the possibilities, impossibility, or probability of such things in the world as free human action, evil, a world without evil. The complex research they contain is often carried out with great precision.

${ }^{10}$ SCHELlenBerg, The Hiddenness Argument, 48.
} 
to understand things. Our understanding of God, derived from religion, as teachers and prophets warn, is prone to individual error because His paths are not our ways, and His thoughts are not our thoughts.

Man, understood generally, as a bodily and spiritual being at the same time, tries, as suggested by these religious traditions, to transcend his understanding adapted to the comprehension of material things and matters of this world, directing his mind towards the First Cause and the Ultimate End. To avoid the danger of idolatry, these traditions developed extensive philosophical and theological systems, distinguishing what can be understood positively about God who reveals himself and what should be understood only negatively. They try to develop a theory of religious language to prevent an anthropomorphic comprehension of the Creator that would conflate Him with creatures, rather than seeing Him as the Ultimate Source, Pure Act of Existence, First Being, Being above beings, or God without being. Equating the Creator with the things of this world and understanding Him like creatures, measuring Being with the measure of contingent things, incomplete beings, is the root of erroneous thinking about God. Furthermore, these things, taken as a measure, according to these traditions, usually do not achieve their fullness, proper to their species, and designed by God as their exemplary and purposeful Cause. Human love and rationality should not be taken as the norm of the divine. If, then, Schellenberg wishes to demonstrate the non-existence of the God of theism, he should construct and examine his argument by working with the philosophical concept of the God of theism and not with the concept of some heavenly loving Omnipotent Superperson, one thirsting for the love of human person and who at the same time has no limitations in creating a world fit for the possibility of a relationship being realized at any moment.

\section{Methodology of PhilosophicAl Theology}

If, in religious traditions, a philosophy of the existence and nature of God is adopted or formulated, then in most cases, the creator of such philosophy either does it top-down, drawing the concept of God directly from his tradition, or bottom-up. Then he faces a problem whether the results of philosophical investigations he formulates apply to God who is worshiped and worshiped in a given religion $R^{1}$. In other words, it is faced with the problem of whether the Being grasped/designated by the content of its philosophical results is, in fact, identical with the God of a given religion, especially if philosophy attributes to people modest powers concerning the scope of knowing God. We deal with this situation in the case of the investigations of Schellenberg, who, in his understanding 
of God, uses the understanding of God in the spirit of Western Christianity, the so-called personalistic theism developed in the 20th-century analytical philosophy of religion. ${ }^{11}$ It is very often the case that this tradition uses anthropomorphic terms. ${ }^{12}$

Philosophy, contrary to the minimalist opinion popular among analytical philosophers, should broaden our cognition. A philosophical knowledge of God cannot simply be a logically correct transformation of religious opinion. But wherefrom should human reason derive cognition beyond the claims of particular religions? It seems that there are only two ways of such understanding that can aspire to claim of reliability. The first is quasi-experiential because it aims to know the existence of God as the Creator, inferring about His existence from the existence and properties of the world. In the course of reasoning coming from the world, the existence of the First Cause, Pure Act, Pure Being, on which the rest of reality depends ontologically, is reached. Only through the analysis and deduction of the attributes of the Being stated in the reasoning, one comes to a limited understanding of this Being. At the same time, its ontic structure, being, due to the Transcendence stated in the reasoning, which is defined as the Necessary Being, Pure Being, Absolute Simplicity, Eternity or Omnipotence, is to be the reason why it is difficult to apply to God human conceptualism and language matching limited beings.

The second method of knowing God, recognized by some philosophers, is purely a priori knowledge. In their opinion, we would have a purely a priori knowledge of the existence and nature of God, independent of our knowledge of the world. The existence of God would, for example, be known intuitively in our mind, in our soul, and at heart, while His nature would be given to us in a priori concept, e.g., as is in the Perfect Being theology of St. Anselm or in Cartesian metaphysics. Proper reflection on the content of this concept is

${ }^{11}$ Ibid., 49-50, 68-69. Cf. Roger Pouivet, “Against Theistic Personalism: What Modern Epistemology Does to Classical Theism," European Journal for Philosophy of Religion 10, no. 1 (2018): 1-19, https://doi.org/10.24204/ejpr.v10i1.1871. Some fragments of Schellenberg's arguments, especially descriptions of the personal relationship, give the impression that the theological concepts and the meanings used by this author are immersed in the personalistic conceptualism of American Christianity in the 20th and 21st centuries. It can be doubted whether, for example, the 19th or 20th-century Russian philosopher would have found a common language with Schellenberg. An example is Boris Wisheslavcev, who emphasizes the importance of the relationship with God's grace and love for the transformation of man; Борис ВышЕСЛАВцЕВ, Этика преображенного Эроса [The Ethics of the Transformed Eros] (Paris: YMCA Press, 1932).

${ }^{12}$ An example of such anthropomorphization is understanding God's knowledge in terms of knowing certain beliefs. Cf. the classical paper of Nelson PIKE, "Divine Omniscience and Voluntary Action," Philosophical Review 74, no. 1 (1965): 27-46, https://doi.org/10.2307/2183529. 
to allow us to deduct individual attributes of God and to know the realm of His possible actions towards creatures.

These two ways of a purely natural, rational cognition of the existence of God overlap to a certain extent in the case of specific philosophical attempts to understand God's nature. They also constitute the basis of the knowledge that the philosophy of religion carries out in a strict sense. The philosophy of religion is a philosophical inquiry into the elements of the phenomenon of various religions, including the religious beliefs that constitute the credo of various particular religions. ${ }^{13}$ They also include beliefs of those religions, their descriptions of God or attributes that God has. The analysis of such beliefs and the meaning of the sentences expressing them is part of many works belonging to the discipline called philosophical theology in the analytical philosophy of religion.

\section{THE NARROW CONCEPT OF GOD IN THEISTIC PERSONALISM}

How does what we have said above apply to Schellenberg's argument? $\mathrm{He}$ uses opinions inspired by Christianity, modifying the concept of God in such a way that he disambiguates it, understanding God very narrowly. However, it does not provide the knowledge that would justify the truth of this construction.

This author tries to convince us to recognize a set of premises about the nature of God. These premises are to establish essential truths about God, his love, openness, and its consequences for the worlds in which God exists. Where does Schellenberg learn about the nature of God? From the tradition of theistic personalism of the analytical philosophy of religion. Where should the addressee of his argument derive this knowledge from? The acceptance or rejection of the premises of an argument should not be a matter of random judgment, some feeling about the premises, wishful thinking. It should flow from the knowledge of their truth.

Moreover, such knowledge presupposes knowledge of reality, which is a correlate of the appropriate propositions. The author of the argument seems to see the matter differently. The basis for accepting the premises is their evident nature. We should be guided by our sense of plausibility of the premises. This, in turn, is to be deepened by thought experiments in which, in the light of our intuitions, we will interpret certain behaviors as open or devoid of openness. On this basis, mainly in opinions about human modus operandi, we should readily see that the premises of the argument about God are evidently acceptable.

\footnotetext{
${ }^{13}$ BocheŃSKI, The Logic of Religion, 52-54.
} 
In Schellenberg's story, the matter looks very optimistic. Well, it seems that however much could be hidden in the nature of God, in the aspect of matters on which the validity of the argument against the non-existence of God depends, these are plausible and even self-evident truths. If there are any difficulties or doubts formulated by the unconvinced, they can be quickly dispelled, taking into account that God is the Almighty. Furthermore, if, in Schellenberg's opinion, these counterarguments against these difficulties do not dispel the doubts, it is evidence of someone's religious bias stemming from her loyalty to a specific concept of God in whom she believes. She should reverse her thinking and abandon her theistic intuitions in favor of some other form of ultimism other than theism.

Are things really as Schellenberg suggests? And especially: Has Schellenberg presented a convincing argument for his view of the matter which he wants to bring round his readers to?

\section{THE TRUTHFULNESS OF PREMISES (1)-(3) \\ OF SCHELLENBERG'S ARGUMENT, THEIR JUSTIFICATION, AND CORRECTNESS OF THE INDIVIDUAL STEPS OF REASONING}

How should we evaluate the value of the first three sentences of Schellenberg's argument? The three conditionals are as follows:

(1) If a perfectly loving God exists, then there exists a God who is always open to a personal relationship with any finite person.

(2) If there exists a God who is always open to a personal relationship with any finite person, then no finite person is ever nonresistantly in a state of nonbelief in relation to the proposition that God exists.

(3) If a perfectly loving God exists, then no finite person is ever nonresistantly in a state of nonbelief in relation to the proposition that God exists (from 1 and 2).

These sentences establish a relationship that is to occur directly between God's perfect love and his openness to a personal relationship with any finite person and indirectly between God's perfect love and the existence of any finite person which is ever nonresistant in a state of nonbelief to the proposition that God exists. Prima facie, these sentences establish the necessary relationship between the two attributes of God, his perfect love and openness, and the second relationship between openness and the non-occurrence of the fact of nonresistant nonbelief in God's existence. The latter fact Schellenberg 
calls the hiddenness of God, or even shorter, the hiddenness. This God's hiddenness does not actually make sense of a hidden God but "is used in a decidedly non-literal sense, as a way of talking about facts that would hide God, were there to be a God." It is about facts that could be given a theistically/atheistically neutral description, like the inculpability of much nonbelief. ${ }^{14}$

Someone might have the impression that the technically and very narrowly and unequivocally understood openness of God is introduced only as a means of showing that God's perfect love excludes the hiddenness. ${ }^{15}$ Regardless of whether such a remark would be accurate, under the transition from (1) through (2) we obtain conditional 3, the consequent of which is the negation of the occurrence of the hiddenness. Furthermore, in the next step, this consequent is negated, which allows Schellenberg, in a valid way, to conclude that there is no perfectly loving God. All this only works with a very ambiguous and narrow concept of these matters. The question of the formal correctness of the transition from (1) and (2) to (3) is not a problem. The problem lies in the acceptance of (1) and (2).

\section{NATURE OF God: DOUBTS ABOUt WhETHER We KNOW \\ What A PERFECTLY LOVING GOD (ALWAyS) DOES}

How should we evaluate these two premises? They are related to each other. However, let us start with the first: (1) "If a perfectly loving God exists, then there exists a God who is always open to a personal relationship with any finite person." How do things look for a researcher who is neither an abstract or religious theist, nor an atheist?

The first reaction that this question may provoke may come as a surprise that such knowledge is expected of us. Let us assume that the inquiry is conducted in a situation where the inquiring persons who read the argument have no knowledge of God. They do not follow any of the theistic religions. They do not know whether the Being called God exists or Who it is. They know neither that it exists nor that it does not exist. If we are in this situation, how would we know if it is the case that if a perfectly loving God exists, then there exists a God who is always open to a personal relationship with any finite person? How would we know that if God were to be perfectly loving, $\mathrm{He}$ would be open to a personal relationship with any finite person?

\footnotetext{
${ }^{14}$ SchellenBerg, The Hiddenness Argument, 16.

${ }^{15}$ Ibid., 14-16.
} 
Moreover, that he would be open because of some necessity, and not because he (only) could be such? How could I know that if God were a perfectly loving being, He would by necessity (always) be open to a relationship with me? After all, I am one of the finite persons. It does not seem that someone who, all things considered, has no knowledge of these matters is making a mistake. However, Schellenberg thinks otherwise.

The problem is that if we are in such a situation, we do not have the faintest idea of God's perfect love and whether there is an essential relationship between such love and God's openness. It is worth recalling that it does not matter whether we mean the de dicto modality or the de re modality for the sake of criticism. The important thing is that it has to be a modality that will secure acceptance of premise (1). What kind of relationship would it be? Does it mean that openness essentially "comes" from the attribute of God's perfect love? Or maybe it is not so, and are they independent but necessarily co-occurring attributes of God? In the latter case, it would also be the case that whenever God is perfectly loving, He is also open to a relationship with any finite being. However, does such a connection even exist? If we knew God's nature, then we could no doubt accept or reject premise (1) on that basis. However, when we do not have an insight into the nature of God, He is not known to us, and the situation is entirely different. In fact, someone could answer that we have no idea how these things are.

Let us emphasize that this is the situation with which Schellenberg deals. $\mathrm{He}$ is convinced that God does not exist. Furthermore, the argument under discussion is not the basis of this belief. ${ }^{16}$ It is certainly not the only or the primary basis of his atheistic view of the world. It also seems that it is not the case that Schellenberg is assuming that we have an insight into the nature of a nonexistent God. There is, in my opinion, the second reason, besides trying to make arguments deductive, why premises (1) and (2) are formulated as conditionals. These premises must be true when the conclusion is true (7). Therefore, if our recognition of this truth is to depend on knowledge of it, then it must be knowledge that we can have independently of our knowledge of God, regardless of the fact of His existence. So, it must be knowledge of the nature of perfect love and its relation to openness to any finite being, which knowledge simply finds application to (nonexistent) God.

\footnotetext{
${ }^{16}$ Incidentally, it is a pity that the author did not give reasons why he became an atheist and why he is currently an atheist. Probably the discussed argument is some of them. Atheism, like belief in God, are not attitudes that are obtained independently of or solely on the basis of philosophical and theological reasoning.
} 
This raises two questions. First, where are we to get this knowledge from? Second, in particular, how do we know that what we consider knowledge is actually knowledge? How do we know that we are not deluded into believing that such an application takes place? If he exists, God can be impenetrable to our intellects, not because he is smaller than we imagine and interpret him, but because he is more excellent. Regardless of whether it was to be taken in the abstract, the knowledge of the essential relations between love and openness, which knowledge supposedly includes as a particular subclass that set of relations that occurs in the case of every (every, any) God, or would it be simply knowing of divine nature, it may be argued that we have no idea whether or not it should include recognition of such an essential relationship. Perhaps God's being is so different from the finite beings known to us that His perfect love, whatever it is, neither leads to openness to a personal relationship with any finite person nor coexists with such openness. Can we rule this out?

\section{A PARTICULAR CONCEPT OF GOD’S OPENNESS}

We cannot assess the value of premise (1) without knowing what openness is. Furthermore, it is specified in premise (2), which defines in entanglement how we should understand this openness. Well, this openness should be so understood that it excludes even one moment of nonresistant nonbelief of any finite person.

It is not so that if (any) God has been open to a particular person, there may be times in that person's life where he may be nonresistant in a state of nonbelief in relation to the proposition that God exists. No, on the contrary, premise (2) clearly states that "no finite person is ever nonresistantly in a state of nonbelief in relation to the proposition that God exists." This condition imposed by Schellenberg on the openness of God greatly restricts the understanding of this openness. However, it also means that this openness, contrary to Schellenberg's intentions and examples, is not predicated on God (and the fictional characters in his examples) in the same sense as we pronounce openness about people in everyday situations. Schellenberg, as is evident from his interpretation of these cases, judges explicitly with certainty that they are examples of lack of openness. The Not Open principle performs a similar function. These matters, however, are not evident even in the case of the example from chapter 5, as opposed to the example from chapter 4. Even more so, they are not evident in the lives of real people and in their application to God.

Understandably, this line of argumentation is needed to conclude deductively (5): No perfectly loving God exists. However, with such a strongly limited, 
disambiguated concept of divine openness, even more significant doubts arise. Namely, why would there be a necessary relationship between such openness and divine perfect love? And why would a perfectly loving God be open-justin this-way?

\section{How Does Schellenberg Justify Adopting PREMises (1) AND (2)?}

In the words of the author of the proof, these claims were developed "on the basis of some careful thought about the nature of God" (38). ${ }^{17}$ Let us start with premise (1) and its notions of perfect love and openness to a personal relationship. This premise conditionally establishes the necessary dependence between the two supposed attributes of God.

If a perfectly loving God exists, then there exists a God who is always open to a personal relationship with any finite person.

This premise is defined as "initially plausible": "Having seen, as you probably have, that the premise looks initially plausible, we now need to inspect it more carefully. Otherwise, we would not be doing our job as philosophers." This premise, when I first became acquainted with it, did not strike me as "initially plausible." Perhaps this is due to the attitude that we should be critical of any proposed arguments, trying to read their structure and content neutrally. Perhaps this is because of the principle that when we begin to make judgments about a God presumed to exist by theistic religions, these judgments cannot simply be taken from our daily experience of finite beings or constitute a generalization of our daily experience. Regardless of the reasons why this premise did not appeal to me and I remained neutral as to its value, it did not seem plausible to me.

\section{WHAT IS GOD'S PERFECT LOVE, AND HOW IS IT RELATED TO GOD'S OPENNESS?}

\section{WHAT IS PERFECT LOVE?}

After the premise is initially assessed as "plausible," Schellenberg goes on to argue for it. He starts by explaining what he understands by the term "perfect love": "Perfect love is the best, the greatest, the deepest love that could possibly be realized in God. It's ultimate love" (39). It seems to confirm that

\footnotetext{
${ }^{17}$ I follow my direct quotations from Schellenberg with page numbers.
} 
the knowledge with which Schellenberg operates is more general than just knowledge of the nature of God. It is the knowledge of love and how such love is realized in God. Love is something that God can participate in, and in Him, it can be realized to the highest degree.

So if God possesses love at all, then this love must be unsurpassably great-more sublime than that of any mere mortal and indeed expressed in an ultimate way.... And even if we can't know everything that perfect love would do or refrain from doing, it may be that we can just see, or that simple arguments can help us see, that it necessarily brings certain things with it... What we want to know here is whether we can just see that ultimate love would necessarily bring with it openness to personal relationship. (40)

Schellenberg sees the problem with our ignorance of what perfect love is. We do not know the full extent of what such love does and does not do. However, we know what it must do. How do we know it? It may be that we just see/understand it, or we see/understand it through simple arguments.

It should be noted at this point that it is not an abstractly understood love that does something but a loving subject that always does it. Schellenberg's approach suggests that this author understands love as an action arising from necessity, as determined by the nature of love. However, in the case of lovea gift, because this is what this should be about, its nature is voluntary. Thus, agape love, Caritas, and gracious love are unnecessary and manifest in many ways. Of course, it may be that the subject of love usually acts in some way. However, the modal may should be emphasized here since may implies it does not have to be that way. This is a severe mistake in understanding love. Perhaps, however, things are different. In numerous places in the book, Schellenberg constructs this story about a loving God as if the love he attributes to God is the love of the need of a loving one, striving for a relationship with his beloved. ${ }^{18}$ This, however, is opposed by Schellenberg's statements, in which he distances himself from understanding openness as God's desire for a proper relationship to take place, for example, in the "Misinterpretations" section. ${ }^{19}$ Schellenberg makes it difficult for readers by not describing clearly what this ultimate God's love is. Perhaps, then, this necessary relationship of openness (always open) with perfect love is based on Eros' love for people? ${ }^{20}$

Recognizing the necessity of the relationship between perfect love and openness is itself necessary to obtain the effect that since the necessary effect

\footnotetext{
${ }^{18}$ Ibid., 43-44, 101, 105-6.

${ }^{19}$ Ibid., 105-7.

${ }^{20}$ Ibid., 100.
} 
of this love is missing, which is the specifically understood openness of God, we are not dealing with love (or more precisely - with a perfectly loving God). We need to remember that it is possible that a perfectly loving God is not open in the specific way Schellenberg defines it. If it were not so, then the antecedent of the first premise could not be denied in the next moves. And thus, it would be impossible to achieve (5), which is also an antecedent of (6) leading by simple reasoning to the thesis of atheism. Then the entire deductive structure breaks down, and Schellenberg fails to reach an atheistic conclusion.

We also remember that the knowledge of this love must be the basis for recognizing premise (1) and indirectly (3). Therefore, Schellenberg wants to avoid engaging with this problem by suggesting to us that even if we do not have knowledge of God's perfect love, we simply understand, or we can see by means of simple arguments, that "ultimate love would necessarily bring with it openness to personal relationship." Therefore, he replaces the argument for truth (1) with the question: "Can we just see that ultimate love would necessarily bring with it openness to personal relationship? But what is a personal relationship?" (40).

When Schellenberg describes a personal relationship between man and God, although he describes it as two-way, he focuses positively mainly on the human side. "This is positively meaningful interaction between persons that they are aware of experiencing each another." It is about relations related to the capacities of mind and heart needed, such as a capacity to feel the presence of God, recognizing it as such, a capacity to exhibit attitudes of trust, gratitude, and obedience to God. He does not pay much attention to the specific nature of this relationship, to the way of entering it and developing it. From time to time, there are comments about it in various places in the book, usually denoting it in terms of negatives. This is one of the weaker moments in Schellenberg's philosophical theology.

\section{WHAT IS OPENNESS OF GOD?}

Once we "know" what type of attitudes or relationships are involved, we can look again at the meaning of God's "openness" involved. At this point in his book, Schellenberg uses what the ancients called a dialectical argument. It appeals to intuitions shared by a significant number of people. Such arguments do not guarantee the truth of the conclusion, even if they are structured in a deductive manner. 
So what is God's openness that is meant here? Schellenberg begins by expressing the idea that openness is to be intuitively known to us. What are our supposed intuitions about? Of course, interpersonal relationships.

Here we've arrived at the very heart of the argument. I expect you'll have a pretty good intuitive grasp of what is meant by "openness" in this context. But let's look at the term more closely, for this will help to expose the great plausibility of the premise in which it appears. I want, in particular, to underline how thin or minimal a notion we've got here. (40)

He believes, or is simply suggesting to us, that we already have an intuitively imposing sense of openness on which we can rely. And when we take a closer look at this term, we can see that premise (1) is very plausible. It now appears that the knowledge of God's openness is based on knowing the meanings of the words of human language to describe the types of relationships between human beings known to us. The matter could be trivial because what language should we speak about God $?^{21}$ The problem, however, is not whose language it is and who shapes it, but what its object is, what its meaning is, and how this meaning should be adjudicated about its object. Schellenberg shapes his narrative in the book as if he did not realize that in the background of the speech about God, there are numerous problems concerning the sense of theological language, ways of thinking and speaking about God, and problems with the occurrence of appropriate reasoning allowing to derive new propositions about God without any logical gap. ${ }^{22}$ Probably, Schellenberg realizes that there have been such considerations in theistic traditions for thousands of years - that they existed even before Christian theology - and only omits them for some reason. ${ }^{23} \mathrm{He}$ seems to be satisfied with the remark at the end of chapter 4, suggesting that we ultimately use language to describe God's love in the same sense as we refer to human love. ${ }^{24}$ However, if it applies to his use of expressions in speaking about God, it only proves the anthropomorphization of his concept of God. It is by no means a point with a normative, regulative meaning on how we should understand terms such as love, which we apply to God.

\footnotetext{
${ }^{21}$ But cf. Maimonides's and Aquinas's views.

${ }^{22}$ Richard SwInBURne, The Coherence of Theism (Oxford: OUP, 1977); Gregory RocCA, "The Distinction Between Res Significata and Modus Significandi in Aquinas's Theological Epistemology," The Thomist 55, no. 2 (1991): 173-97.

${ }^{23}$ These problems were studied by Middle Platonists (1st-3rd centuries BC). Damian MrUGALSKI, "Agnostos Theos: relacja między nieskończonością a niepoznawalnością Boga w doktrynach medioplatoników," Roczniki Filozoficzne 67, no. 3 (2019): 25-51.

${ }^{24}$ SCHellenberg, The Hiddenness Argument, 48-49.
} 
Let us go back to the concept of God's openness proposed by Schellenberg. He emphasizes that this concept is minimal, comprising the lack of action that would make it impossible to remain in an appropriate relationship for the creature seeking such a relationship at a given time. God's openness to a relationship does not require that God do any particular thing to pursue a relationship:

No, being open in the relevant sense at a certain time simply means not (then) being closed. It means not through one's own actions or omissions making it impossible for the other, whom one loves, to participate in personal relationship with one at that time should the other wish to do so.... It means that it will be possible for creatures ... to participate in relationship with God; if they want to, they will be able to do so simply by trying to do so.... If thus open to relationship, God sees to it that nothing God does or fails to do puts relationship with God out of reach for finite persons at the time in question. (41, emphasis mine)

Even if it is a minimal concept of openness, it is pretty logically complicated. Let us skip the question of how we know that a particular state of affairs proves that S's does not act to prevent it, and it is not the case that there is another reason for the failure of a given relationship. Another thing is that such an innocent-sounding term of minimum openness can be read as an expectation of possible participation in a relationship with God at will. At a lower stage of intellectual development, someone from the old epochs could treat such an expectation as an expression of an utterly non-minimal claim.

It is essential to recognize that the element which, according to Schellenberg, is a necessary condition for a personal relationship between God and man of a kind worthy of interest (for God and man) is being convinced that God exists. ${ }^{25}$ It is not God's action of different types, nor the vague factual knowledge of God, which is not recognized as such. It is also not a search, desire, or striving for God that does not contain a psychological judgment that God exists. Nor is it the direct consciousness of God that is not expressed in any belief about God. What is a necessary condition for this desired relationship from the point of view of perfect (and imperfect human) love is the conviction that God exists. God that is minimally open will ensure that this condition is not compromised.

Of course, if we want to rely on an intuitive grasp, things can seem positive. If we were God, would we not make sure that a relationship with us was not beyond the reach of finite beings? Is it the same as making sure it is ondemand? Possible at any time, as we would like, as these finite beings? Maybe

\footnotetext{
${ }^{25}$ Ibid., 58.
} 
yes. Perhaps not. Someone might suggest that it depends on what circumstances the person would be in and what we would like for him, and how the result of this minimal openness would relate to these goals. However, Schellenberg has a prepared reply to this. I will return to this in what follows.

\section{ARGUMENT FOR THE NECESSARY RELATIONSHIP OF MiNIMAL OPENNESS WITH PERFECT LOVE}

Schellenberg's reasoning is as follows. Schellenberg asks whether God can have the quality of perfect love and not be open in this minimal sense. $\mathrm{He}$ replies that this is not possible. To be exact, he does not say it outright. $\mathrm{He}$ states this in a roundabout way by assigning such an expectation to the main premise of the argument: "Could our definition of perfect love rightfully be deprived of even so weak a relational condition as is represented by the phrase 'always open' when it is taken in this minimal sense? The main premise of the hiddenness argument expects that you will say no" (41).

Of course, this is a kind of metaphor-a metaphor of the expectation of the central premise of the argument that we will say yes to the necessary connection between the perfect love of God and that (His) thin openness. Otherwise, we will not find premise (1) convincing. It is true. Nevertheless, of course, that metaphorically speaking is not the evidence of the truth of (1), it is not any philosophical argument for the truth of (1). It is not a justification of its plausibility!

It seems that Schellenberg does not present any ontological argumentation in Chapter 4 that minimal openness thus understood is essentially contained in perfect love. Instead, he states that the truth of the sentence in question is self-evident in itself: "Such minimal openness as we've identified seems selfevidently to belong to divine love" (41). It is a matter of intuitive vision. ${ }^{26} \mathrm{~A}$ declaration of the self-obviousness of a particular statement or fact for Schellenberg does not, however, constitute a convincing argument for others.

It is not that Schellenberg does not argue at all. He presents an argument of a different kind. It describes the constructed situation of a child of parents who are not interested in contact with their son. He suggests that we can deepen our (allegedly) intuitive understanding of the truth of this necessary relationship of love with openness by presenting ourselves with situations

\footnotetext{
${ }^{26}$ This reminds me of the teachings of my logic teacher from the period of my university studies, Stanisław Kiczuk, who suggested that we should always pay special attention to those statements that are referred to as self-evident.
} 
from human life. The description of this situation is to be reduced to the absurd belief of a fictional character of a friend who believes that his parents so wonderfully love him, and at the same time, they are not open to being in a relationship with him - at least not at that time.

One may agree that a situation constructed as Schellenberg does, is absurd. It is so because part of its structure is the lack of openness to the relationship with the son. We can even agree that a reasonable explanation for this lack of openness is a lack of love. Let us agree but remember that we are dealing with an outline of constructing the description of fictional characters. Let us assume this entire paragraph is relevant. Does it follow from this description, however, that in the case of a partially analogous situation where God's preventing of a personal relationship between some person and God, it is impossible to obtain both, such preventing and perfect love of God? Even assuming that preventing is understood strongly, as doing something, hence some person doesn't believe that God exist. Is it impossible? Isn't it evident that it is? I do not think so.

Arguments from analogy are fallible, and what Schellenberg needs in the first place is to justify the assumption that such an analogy exists at all and that the above paragraph can be applied to understanding the relationship of a loving God to His creatures. The only impression one gets after reading this paragraph is that this passage uses some common view of God, who is like a human parent. Moreover, his love can be measured with the help of anthropomorphic conceptions of relationships in a correctly understood parental love. This type of argumentation is not an example of a valid philosophical argument if we understand philosophy as a careful inquiry about the essential nature of God.

The above paragraphs only tried to undermine the view that we have obvious knowledge that would make it possible to rule out the falsehood of premise (1), even with such a minimal understanding of openness. We have not argued here that we know that God actually prevents a particular person from entering a personal relationship with Him at time t. We are just saying that we do not know that it is impossible. Even if the argument from interpersonal relations were valid for humans, it does not have to be valid for God. Assuming the analogy to occur, Schellenberg does not exclude, contrary to what he thinks, the last possibility. Moreover, the mere use of an analogy as even partially justifying the ascription of openness in its sense of divine perfect love itself requires justification. 
Let us summarize. Schellenberg's position is that it is impossible that God loves us perfectly and is not open in this sense. According to him, it is a claim evident in itself. Furthermore, to deepen the understanding that it is true, we should see the alleged fact that parents do not have the appropriate openness in an allegedly analogous situation. Unfortunately, neither of these claims fully supports the thesis that perfect love logically entails openness in a minimal sense. This is self-evident truth for me. Thus, Schellenberg is still burdened with proof of the truth of this modal theorem.

Let us leave the link between openness and God's perfect love; we will come back to that in a moment. It is possible to argue with Schellenberg differently about the notion of openness. It can be argued that God is open, although in a slightly different sense than Schellenberg constructs. Then premise (1) is true, and premise (2) is false. In such a situation, it would be possible for a perfectly loving God to be open, and at the same time, someone does not know if God exists but would like to know it.

\section{THE DIMENSION OF GOD’S OPENNESS IS RELATED TO TIME}

We should draw our attention to the moment of temporal determination of openness, which is vital in the argumentation. Schellenberg, arguing in the example of parents-son for the connection of perfect love with openness, introduces the time to the argument from hiddenness. His point is to secure the temporal interpretation of God's attributes in this way and to be able to relate it to the temporally understood hiddenness. It is also an opportunity to present openness so that it does not allow the temporal hiddenness of God.

In the above context, the topic of the temporary postponement of the realization of the conscious and lived relationship between creation and God appears for the first time. Schellenberg raises this point in the following text:

Being "closed" suggests never making a personal relationship possible. But such, it may be said, is certainly not the case with God. Even if at a certain time I am unable, just by trying, to participate in relationship with God then if I want to, God may still make it possible for me to do things that will give me such an ability in the future. Shouldn't this count as a sort of openness to personal relationship on the part of God? (42)

The point is essential because we are dealing with an eternal God who does not have to be understood as "entering into a relationship with his creation at a given moment," now or never, since both members of the relationship have 
eternity before them. ${ }^{27}$ Again, Schellenberg seems to be aware of this. Therefore, he insists in the paragraph under discussion that we must not get distracted: "It is important not to get distracted from this point." If someone tried to associate God's openness with making it possible for someone to do things that would give someone such an ability in the future, it would be a "distraction."

We cannot but regard Schellenberg's movement here as rhetorical. The God of theism is eternal and knows a person's entire life. As theism suggests, God is present at all times in a person's entire life through his creative activities and the relationship of competition with his creature. Remember that we are considering these things from a neutral perspective, simply by understanding the position of theism. The idea that God understood in such a way, in His perfect love and knowledge, can associate a given person with a chance for a fruitful personal relationship at the moment other than the one in question, is not a distraction, but an opening possibility of understanding the openness of God. Let us add, it is a concept of openness that undermines premise (2) and indirectly (3). Why should we not explore this possibility but treat it as a dead-end? Again, contrary to Schellenberg's words, an analogy with the human understanding of openness and the belief that "it seems rather odd for someone to take as a goal someone else's openness to personal relationship with them while holding that they are already unsurpassably loving toward them" (42) are not a sufficient argument.

In the following stage of his argumentation for the truthfulness of the premises, he will try to move from sometimes to always. Schellenberg, when discussing the distinction between love and benevolence, notes that "everyone ... will accordingly be able to agree on at least this much: divine love at some time must involve openness to a sharing relationship of the sort we've been talking about. Otherwise it obviously couldn't be the greatest love possible" (ST) ${ }^{28}$ Let us accept the truthfulness of the above sentence. However, does the following principle ET result from it? We read: "The greatest possible divine love at every time must involve openness to a sharing relationship of the sort we've been talking about" (ET). Of course not. To think that ET follows logically from ST under the simple implication ST $\rightarrow$ ET is itself a logical fallacy. Nevertheless, perhaps there is some argument that shows that the above implication is true? What does Schellenberg say? He implicitly

\footnotetext{
${ }^{27}$ This way of speaking does not involve the negation of God's timelessness. Cf. Eleonore STUMP and Norman KRETZMANN, "Eternity," Journal of Philosophy 78, no. 8 (1981): 429-58.

${ }^{28}$ SCHELlENBERG, The Hiddenness Argument, 43-44.
} 
suggests that we should acknowledge the above implication. However, he does so not with an appropriate argument but with a question that suggests it is happening: "Moreover, suffering from no limitations of knowledge or power or (therefore) of resourcefulness, an unsurpassably loving God clearly would love finite creatures at every time when they exist. Doesn't openness at every time follow?"29

Does it not follow that an unsurpassable loving God clearly would love finite creatures at every time when they exist? Two things should be noted here. First, the sentence "(the greatest possible) divine love at some time must involve openness to a sharing relationship of the sort we've been talking about" (ST') is a sentence about the relationship between God's perfect love and openness ${ }^{\mathrm{Sch}}$ at the time $\mathrm{t}^{\mathrm{n}} \cdot{ }^{30}$ On the other hand, the sentence "suffering from no limitations of knowledge or power or (therefore) of resourcefulness, an unsurpassably loving God clearly would love finite creatures at every time when they exist" (ULE) merely states that divine love extends to every moment of the existence of loved creatures. The relationship between ET and $\mathrm{ST}^{\prime}$ is not obvious but let us agree that they are consistent. So, does this conjunction ST' and ULE show that ET is true? No, it does not follow. Let us omit here that the term should not be applied to the love of God but only to the effects of the openness in question. Assuming that we understand what he is saying correctly (taking into account the timelessness of God), "at the same time" does not lead to "at every time."

From the sentence

Sometimes I call my daughter because I always (invariably) love her.

it does not follow that

I always call my daughter because I always (invariably) love her.

It does not follow from the truthfulness of the first sentence that it is impossible to negate the second! Thus, contrary to Schellenberg's suggestive question, it does not follow that there cannot be such a time that there will be no lack of technically understood openness ${ }^{\text {Sch }}$ of God in a limited time-even when it is true that God loves His creation at any time. It would be a logical fallacy to admit that it does follow. Perhaps that is why Schellenberg is content only with the question "Doesn't openness at every time follow?".

\footnotetext{
${ }^{29}$ Ibid., 44.

${ }^{30}$ By the index ${ }^{\text {Sch }}$ I mean Schellenberg's specific understanding.
} 
Things are even worse for Schellenberg's argument. Not only is there no simple derivation from sometimes to always, and not only did he not present an argument allowing him to conclude that in the case of God, however, such a derivation does occur, but also arguments may be supplied to undermine statements such as ET and (1). They will indicate situations in which particular circumstances mean that the realization of the good of a loved one depends on the temporary lack of a cognitive relationship with the person who loves him.

\section{TO DEFEAT (ALL) POSSIBLE DEFEATERS}

Schellenberg is aware of this, and to this end, he makes a two-stage argument for eliminating such defeaters. "But something else that might inhibit this realization is the fact that non-ordinary circumstances can be imagined in which human beings might be loving without openness of the sort in question - at least for a while" (44, emphasis mine).

First, this fragment is interesting in yet another way. We know that Schellenberg distinguishes between benevolence and love: "Love entails benevolence but goes beyond it too." However, the phrase "indeed, the benevolence part of love might conceivably come in conflict with the openness-to-relationship part" suggests that love should be contrasted with benevolence. This would be the case if love were understood to mean the pursuit of one's own good, and benevolence consists in giving or not obstructing the obtaining of some good. On such an interpretation, an action aimed at not obstructing the achievement of good by a loved one (a daughter Sally) would conflict with the good of the personal relationship between her and her father, Fred. This one would require Fred to reveal himself to his daughter.

Interestingly, Schellenberg makes it clear that Fred is not open to a relationship with her at this time in such a situation. ${ }^{31}$ This is a very strange assessment. This passage, in my opinion, clearly indicates a very bizarre misinterpretation of the concept of openness that Schellenberg uses in his argument and in his own understanding and assessment of it. Indeed, things like openness and closeness of one person to another are not like events. They are not instantaneous but are of the nature of phases. In other words, they are usually long-lasting. This is true of people's attitudes. All the more so, if such temporal

31 "So Fred holds off. Now, by doing so he prevents Sally from being able to participate in relationship with him just then, which means he's not open to relationship with her just then. But isn't this kind and even loving of Fred, rather than un-loving?" (44). 
definitions can be ascribed to God at all, they should also be understood as permanent in relation to God. The reason is the unchanging nature of God of love. What we observe in the described story of Fred is consistent with his long-term openness in the ordinary, everyday sense and with his desire for a relationship with his daughter. It is precisely because he is open that he is looking for her.

So, the fact that Fred holds off is not proof that he has lost his openness to her. However, in Schellenberg's special sense of openness ${ }^{\text {Sch "he's not open }}$ "sch to relationship with her just then." Let us agree that this is true in this particular Schellenberg's sense. The point here is that the standard concept of openness does not exclude hiddenness, unlike openness ${ }^{\text {Sch }}$ does.

It becomes therefore necessary to distinguish between unusual and normal situations and acknowledge that "the best love normally or ordinarily is open to relationship at every moment of its existence" (44).

Someone may start wondering why the precision of the last rule for typical situations is made in words that seem pertinent to unusual situations "the resources to accommodate the possible consequences of such openness, making them compatible with the flourishing of both parties." 32 It becomes understandable when we remember that we are interested in God's openness here. Schellenberg is concerned that the qualifier "normally" may seem to introduce an uncertainty of truth of (1) and (2) with relation to openness of God.

\section{ANYTHING (WORTH PURSUING) Is POSSIBLE WITH OMNIPOTENT AND PERFECTLY LOVING GOD}

We now come to a critical point in Schellenberg's argument. The correctness of his argument depends on this case (but not only on it). Schellenberg knows this. And we should also be aware of this. Due to possible defeaters of his concept of openness, Schellenberg pulls out a cannon and then fires a shot. The cannon is the attribute of omnipotence, and the shot is the assumption of the truth of what is still under scrutiny!

Therefore, in order to avoid situations that undermine the general principle assumed by part of reasoning (1)-(3), Schellenberg refers to the attribute of omnipotence: "God has the resources to accommodate the possible consequences of openness to relationship with finite persons, making them compatible with

\footnotetext{
32 "In other words, and a bit more precisely: things should be expected to be so wherever the lover has the resources to accommodate the possible consequences of such openness, making them compatible with the flourishing of both parties and of any relationship that may come to exist between them" (44-45).
} 
the flourishing of all concerned and of any relationship that may come to exist between them" and "if God exists as an omnipotent creator and an infinitely rich personal reality, then God can make it so."

Here we are discussing the nature of God - the love and openness of The Almighty. The God of theism is almighty. Of course, it does not follow that we can decide concerning any action whether it is within God's power. Even if God could do anything possible and is all-powerful, there remains the task of proving that God has the resources to make any possible consequences of openness compatible with the flourishing of all concerned and of any interesting relationship that may come to exist between them. From the point of view of logic and conditions of epistemic justification of his position, Schellenberg cannot just assume that.

Furthermore, he should not assume that "if also unsurpassably loving, God would make it so." Because Schellenberg's argument is to justify premise (1), and here it is simply based on it. Acceptance of the sentence quoted is begging the question.

It is not that attributing omnipotence to God is attributing to God the ability to do anything. There are many things that Almighty God cannot do. ${ }^{33}$ This seems to be a bonum commune of analytical philosophy, and even if there is no general agreement on the positions presented in the debate that has been going on for decades, Schellenberg's position is not evident. Moreover, its truth should be proved. For even if God is omnipotent, why should this rule out the possibility that there are ways of God's acting and realizing His openness that are consistent with Schellenberg's temporary lack of openness in the technical sense and which will result in a much better personal relationship between man and God?

Again, Schellenberg, who has been defending his argument for a quarter of a century, seems to be aware of this. Therefore, he tries to answer this objection in a rather vague way. Almighty and perfect love allow us to anticipate the worlds that God will create: "But if we assume that God is a divine person who will create, and will create finite persons, and thus that unlimited and unsurpassable love is to come their way, then in effect we have a statement being made about what sort of world the actual world shall be" (46).

More precisely, the above sentence allows us to exclude that God would create a world where there may be a conflict between God's openness and some human goods related to God, who will strive for human possession of

\footnotetext{
${ }^{33}$ Marek PePLIŃSKI and Martyna KoszKa£o, "Wszechmoc," in Przewodnik po filozofii religii: nurt analityczny, ed. Janusz Salamon (Kraków: WAM, 2016), 37-59.
} 
them. There are no anomalous states of affairs like nonresistant nonbelief with some goods that justify them in such a world. This is merely a reiteration, in other words, of the argument that "God has the resources to accommodate the possible consequences of openness to a relationship with finite persons, making them compatible with the flourishing of all concerned and of any relationship that may come to exist between them." It is assumed here that God has the appropriate power. Perhaps he has such power because he will not plan for limited beings any goods incompatible with his openness. Schellenberg does not consider whether there are (or are not possible) much greater goods that do not meet these two conditions, closing the discussion with a conventional "conclusion" concerning what Almighty Love will do: "If also unsurpassably loving, God would make it so." Just like acceptable goals that a father and husband will set for himself, due to his life roles, God will not pursue goals that would require a temporary limitation of His openness.

Again, Schellenberg's argument follows the principle that what is right about man should be treated as right about God. However, let us leave the question of value of reasoning by analogy. Suppose Schellenberg wants to use the principle that a perfectly loving God creates only such worlds that all goods God pursues are relationship-compatible goods in any created world. ${ }^{34}$ In that case, he must demonstrate that this "only relationship-compatible goods" principle (ORCG) is not merely an apparent resolution to the problem of whether almighty God can achieve certain goods compatible with the personal relationship in question.

He needs to show that such a God should not have acted otherwise or that it would not have been better if $\mathrm{He}$ had acted otherwise. For it is possible that the worlds that the creator God chooses according to the ORCG principle turn out to be very poor in terms of good. For it may be that only some kind of trivial good is available in the ORCG worlds. Alternatively, it may be that while there are some non-trivial goods in these worlds, in the worlds that are not realized according to the ORCG framework, there are far greater goods that can only be achieved in the absence of a personal relationship of some creatures to God temporarily. Moreover, it may be argued that existence in such worlds is better for its inhabitants, and therefore it would be better if God did not follow the ORCG principle in creation, or even that he should not do so.

Schellenberg appears to recognize the importance of this defeater. In any case, his statements that follow can be interpreted as an attempt to neutralize this type of trouble. To this end, it introduces the principle which we can

\footnotetext{
${ }^{34}$ SCHELlenBerg, The Hiddenness Argument, 47.
} 
formulate as: "No problem, (personal relationship with) God is the solution for all goods" (NPGiS): "For any good improving the lives of finite persons that might seem to require God to be for a time closed to relationship with us, there has to be a way for us to achieve that good, or a good of that type, in and perhaps precisely through relationship with God." ${ }^{35}$

Schellenberg believes his statements here are somewhat abstract. This is true, although the idea he uses is intriguing. This, however, does not contradict the following.

First, in order to apply the NPGiS principle, Schellenberg must prove that it is true. He did not do that. He just put it forward. Second, this principle appears to be false or unimportant for two reasons: (a) even if all the good of creature consisted in participation in the good of God, the essential goods in which creature can participate by participating in God may require a temporary lack of a personal relationship in question. (b) Even if all the good of creature consists in participation in the good of God and is such that it can be achieved faster through a relationship with God, it is possible that essential goods in which creature can participate by participating in God through relationship ${ }^{\text {type a }}$ with God at time $t^{1}$, would require the lack of belief in God at $t^{1}$ in the sense essential for Schellenberg's argument.

We can also argue otherwise. (c) Even if all the good of some person consists in participation in the good of God, it is possible that the essential goods in which that person can participate by participating in God are available (according to the measure of good which is God), only through the lack of belief in God in the sense essential to Schellenberg's argument at a particular time $\mathrm{t}^{1}$. Schellenberg must convincingly rule out each of these situations in order to make the use of NPGiS in his arguments convincing.

\section{ONCE AGAIN ABOUT THE OPENNESS OF GOD—NOT OPEN PRINCIPLE}

Earlier it was suggested that it is possible to understand the openness of God differently, closer to the colloquial understanding of the term than it is to Schellenberg's. At the same time, it is closer to the metaphysical theism of Christianity and the other two theistic religions. It is a concept of openness that is not instantaneous in the Schellenberg sense. Let us note that predicting the God of openness in the sense of Schellenberg is predicting it at some temporal point $\mathrm{t}^{1}$. In the next moment, $\mathrm{t}^{2}$ God may not be open or be but again in relation to that moment. Schellenberg will, of course, defend the claim that

\footnotetext{
${ }^{35}$ Ibid.
} 
Almighty Perfect Love is open at all times. After all, this is what his argument is partly about. It does not change the fact that this kind of God's being open is a particular type of time event (or at least such an interpretation is imposed).

Meanwhile, openness to relationships in our human world is something enduring. If we try to transfer this understanding to God, what Schellenberg does by justifying claims about God with examples from human situations, we should consider our actual common intuitions. Schellenberg, instead, modifies them to reinforce his argument. Those that may lead to the rejection of the premises of his argument are stopped by ad hoc rules such as NPGiS, ORCG, NO, etc.

Well, this concept of permanent openness is compatible with situations in which specific circumstances cause that the realization of the good of a loved one depends on the temporary lack of a cognitive relationship with the person who loves him. There may be reasons for God not to help a person attain knowledge at time $t^{1}$ that he exists; if God knows that it would result in less good than he will do if he knows it at time $t^{2}$. Another reason could be a great evil that will affect this person or other people which God knows will happen if that person believes in His existence at $\mathrm{t}^{1}$, but it will not happen when that person believes in time $t^{2}$. Schellenberg wants to stop this type of interpretation of (1) and openness in (2), which, while maintaining (1), led to rejection (2), using the ORCG and NPGiS principles. However, as has been argued before, their application is not a part of philosophical argument unless it is demonstrated that they are sound and valid and that they exclude the situations for which exclusions are designed. This Schellenberg did not do.

Let us finally examine Schellenberg's argument for the Not Open principle. It says:

If a person A, without having brought about this condition through resistance of personal relationship with person $\mathrm{B}$, is at some time in a state of nonbelief in relation to the proposition that B exists, where B at that time knows this and could ensure that A's nonbelief is at that time changed to belief, then it is not the case that B is open at the time in question to having a personal relationship with A then. (56-57)

How does Schellenberg try to justify the Not Open principle? Again, we have the statement of "the plausibility of a certain general principle about openness and non-openness" and the statement that "it identifies a condition in which, at a certain time, a person B clearly is not open to relationship with a second person A" (56). The introduction of the principle takes place with the help of the case of an adopted child and a mother who, having given up the child, has the opportunity to inform him about her existence, but she does 
not. Such a modest story does not prevent Schellenberg from answering the question about this mother's openness negatively: “Just as we saw in the previous chapter, in connection with a somewhat similar example, the answer is clearly no. Let's generalize from this example and produce our principle" (57).

It is by no means obvious. In order to answer the question of whether the mother is in a significant sense open to the relationship with the child, it is necessary to know her motives and aspirations. We should know if she desires and strives for such a relationship, but for some reason, does not make her child find out about it. The opposite, knowledge that the above possibility does not exist is equally essential. Note that the situation of the described openness $^{\text {wo }}$ ('wo' stands for wider openness) is compatible and includes being not open ${ }^{\text {Sch }}$ in the Schellenberg sense, at particular time. Therefore, we deal with different meanings of openness. Of these different options, Schellenberg simply goes for a narrow understanding of openness ${ }^{\text {sch }}$, which is consistent with the choice of a narrow range of activities and inconsistent with the broader spectrum of activities available, such as for example, leading to the knowledge of the mother's existence at a different time when it will not conflict with some of the interests of the child and mother. The latter is consistent with openness ${ }^{\text {wo }}$.

The very fact that the understanding of openness is not the only possible one makes Schellenberg's assessment that it is evident that the mother is not open to meeting the child not valid. In other words, Schellenberg's decision in the case of this particular fictional mother figure may be true, it may be false, and it is certainly doubtful.

We remember that in all the cases constructed by Schellenberg there are doubts as to whether they are correctly interpreted as models of non-openness ${ }^{\text {wo }}$ in the colloquial sense, although they meet the author's specific criterion: at the moment $\mathrm{t}^{1}$ an open person acts so as to inform about his existence. Schellenberg may introduce a definition to regulate openness, but we may question it. We must also remember that the openness that Schellenberg talks about, that is, openness $^{\text {Sch }}$, is not openness in the sense we attribute to people. This is because it allows the failure to be notified of someone's existence for the sake of important goods. Schellenberg wants to interpret God in an anthropomorphic spirit, using examples of relationships between people. This is a kind of mistake. In reality, however, he uses modified concepts, the application of which to some human situations would not allow, without additional knowledge, to decide whether a given person is open or not. Based on the generalization of such decisions in constructed cases, Schellenberg introduces NO. 
Schellenberg anticipates possible doubts regarding this principle by asking the question: "In these circumstances, how could it still be the case that B is open to a meaningful, conscious relationship with A then?" Schellenberg also provides a definitive answer. "After all, by not revealing herself, B is doing something that makes it impossible for such a relationship to exist at that time, and this, according to our definition, is precisely what is involved in not then being open to it" (57). However, that was not what he was asking. The question was how to understand openness, not whether Schellenberg's definitions and intuitions are consistent.

The problem is that understanding who a person is and what attitudes they de facto adopt cannot be obtained simply through a precise definition that regulates the colloquial notion of a given attitude. It always requires carrying out specific tests, also trying to exclude our hypothesis about the lack of openness. We set up a straw man otherwise. In particular, one should not establish an attitude, or the lack of it, by defining it so narrowly that it necessarily contains effects which its absence may in fact permit.

Then the author applies NO to God. God possesses all relevant knowledge and ability. So if some finite person is ever nonresistantly in a state of nonbelief in relation to God's existence, then there is no God who is always open to a personal relationship with any finite person. ${ }^{36}$

The application of this principle to God encounters two difficulties, the specific one related to the theistic concept of God's eternity ${ }^{37}$ and the general one related to the application of openness ${ }^{\text {Sch }}$ instead of openness ${ }^{\text {wo }}$. First, the researcher who thinks about NO need not accept the temporal understanding of NO. If God is immutable, He has only timeless attributes. If God has the attribute of openness, He always has it. Ascribing the attribute of time to God because the effects of God's actions due to this attribute are time-determined is groundless and invalid. The God of theism is not related to the world so that one can unequivocally infer God's temporal determination from the temporal determination of the effects of his action.

However, what is essential is how we should understand openness in the spirit of Schellenberg or, more broadly, and whether nonresistant nonbelief in God at some time $t^{1}$ is or is not proof that that there is no God open at every time. Assuming that openness is an operative attribute-an action/attitude consisting in aiming/striving for effect-a relationship with another person for a long time, and that it assumes, among other things, as a condition of such

\footnotetext{
${ }^{36}$ SCHELlEnBerg, The Hiddenness Argument, 57.

${ }^{37}$ I stand for the timelessness of God.
} 
a relationship, the desire to reveal your existence to the other person at some time buy not in every time, failure to reveal one's existence at some time is not evidence of lack of openness. However, this matter requires much more space for a fuller discussion.

\section{FINAL REMARKS}

Let us summarize the results of the research presented in this article so far. In its first part, we tried to justify the claim that rational, human knowledge about God, about His nature and existence or non-existence, is not easy to obtain. This does not mean that it is not possible. It appears to be obtainable in several ways. It seems that the nature of who God is or could be is available to us to some extent. Another issue is the assessment of the value of such knowledge, its accuracy, or certainty. However, it is not that these matters are obvious; regardless of the sources of knowledge about God and the nature of such knowledge, getting to know the truth in this area requires a great deal of inquiry, reflection, consideration of different points of view, and constant re-evaluation of known answers to the same questions. It also seems to require an appropriate spirit, or perhaps sensitivity to the mystery of the world. Putting the matter entirely from a religiously neutral point of view, the world appears as one that reveals the existence of God, His Providence and Greatness. At the same time, it has features that seem to testify against the existence of God. This trait can be seen by presenting things abstractly, from the general philosophical point of view of understanding the world and answering metaphysical questions about the truth or falsehood of theism. Some aspects of the life of some people seem to testify against the existence of God in the light of their understanding. Some of them are believers and keep their faith against all odds. Others lose it. Some people never seem to have it. How to understand this?

If we have a rich imagination and creative skills, we can formulate various hypotheses. They explain better or worse some, and sometimes most of the things that testify for and against God. It does not seem that any set of theorems would explain them all. The search for understanding always remains an incompletely realized endeavor. For the sake of this search, it seems that it should not be filled with an unreasonable certainty that our interpretation of these matters is undoubtedly correct. Does this mean that we should not strive to use deductive reasoning in philosophical theology? On the contrary, but we 
should be aware that if we take non-obvious premises as evident, we risk making a mistake in a very important area.

Let us talk about the method in a more detailed way. Schellenberg urges the reader in numerous places to think philosophically and be impartial. Is he himself impartial in his research on the value of an argument from hiddenness? Is excluding the examination of options where hiddenness turns out to be the actual hiddenness of God an expression of the approach being impartial? Or is it an expression of a biased limitation on how to interpret the problem? Note the way Schellenberg's argument is made in point (i) of the "Goods" section, ${ }^{38}$ how Schellenberg distances himself from the beliefs that differ from his viewpoints. He notes that from the perspective of their beliefs, some things may be understood differently. Then he notices that the philosophical approach to these matters requires that:

One has to drop the assumption that God exists and that everything somehow fits God's plan (atheism can't even be taken seriously if that's one's frame of mind!), mentally bringing together the two relevant concepts: the concept of a finite person at least initially disposed to respond negatively to God, and that of a creator of all, a Person unlimitedly wonderful and resourceful. (64)

There is no room here to discuss all the relevant methodological theorems and concepts used in The Hiddeness Argument by Schellenberg. Brief remarks must suffice:

a. The question of the existence and non-existence of God in the light of this argument should be approached from a perspective that considers not only the possibility of atheism but also the possibility of the truth of theism.

b. It should not disregard various theological concepts of God and possible situations. Otherwise, it is simply highly possible that a God who will be found to be non-existent will not be the God of theism but some dubious construct of narrowly and incorrectly understood theology.

c. Instead of confirming his position, Schellenberg should try to refute it by subjecting it to the strongest tests. Instead, he tries to defend it with the help of debatable theoretical solutions that he accepts.

$\mathrm{d}$. The philosophy of religion, as well as philosophy in general, can be made both in engaged and disengaged way of philosophizing.

In any case, this should be done impartially and with an openness to changing one's understanding of matters. Such openness implies impartiality consisting

${ }^{38}$ Ibid., 60-64. 
in, among other things, that we judge the credibility of an argument based on its justification, logical correctness, and relation to what we know about the world that is happening or that is possible or impossible, probable or improbable. Note that regardless of the deductive form of the argument of hiddenness, most of Schellenberg's reasoning, if it has a justifying function at all, is a partial justification. At best, it points to the probability of the premises.

At the beginning of the text, I suggested that we are dealing with some kind of error in the case of premise (6) ("If no perfectly loving God exists, then God does not exist"). If I am allowed to express my views on these matters, this sentence seems to me to be completely counterintuitive. How would we know that, even with the various arguments that God should be perfectly loving, there is no God who is different from what we think He should be? The doctrine that God is love-albeit love in a different sense than that postulated by Schellenberg - was brought by Christianity. However, apart from the teachings and example of Christ, does Schellenberg's reasoning provide us with the knowledge to acknowledge truthfulness of (6)? I disagree.

However, let us run a thought experiment. Let us treat this whole argument (which is a very narrow way of understanding God and His way of managing the creation) as a test of the theistic hypothesis, with some specific understanding of the terms involved. Let us now make a friendly move towards the author of the argument. Let us accept the argument based on the recognition that our world is its model. The concepts of perfect love, openness, and omnipotence are understood here unambiguously in Schellenberg's way. The approach to God he proposes ignores the entire spectrum of possible ways of understanding the realization of God's perfect love, his much richer openness, which, however, would sometimes result in a different way, moment, and stages of entering of some beings into a relationship with the Creator. Let us call the (perfectly loving) ${ }^{\text {Sch }}$ God such a God ${ }^{\text {Sch }}$ who fulfills Schellenberg's narrowed conditions of perfect love, namely that the world created by such $\mathrm{a} \mathrm{God}^{\text {Sch }}$ does not contain unresisting unbelief. When treating (1) and (2) as hypotheses about God $^{\text {Sch }}$ (who loves perfectly) ${ }^{\text {Sch }}$, where these premises partially define $\mathrm{God}^{\mathrm{Sch}}$, we can treat the reasoning from (1) to (5) as a falsification of the hypothesis of the existence of such a God. Let us remember how physics is done. Falsifying a physical hypothesis about some aspect of the material universe does not always lead to the rejection of the object of study but calls for the formulation of a new, better hypothesis. Similarly, the rejection of the existence of God $^{\text {Sch }}$ with a specifically understood (perfect love) ${ }^{\text {Sch }}$ is not sufficient to deny (every) God a perfect love that results in other actions, and it does not follow that no God exists. 
The following reasoning is not correct.

(5) No (perfectly loving) ${ }^{\text {Sch }}$ God exists (from 3 and 4).

(6) If no (perfectly loving) ${ }^{\text {Sch }}$ God exists, then God $^{\text {Sch }}$ does not exist.

(7) God does not exist (from 5 and 6).

Because from (5) and (6) what follows is not (7) but (7) ${ }^{\text {Sch. }}$

$(7)^{\text {Sch }}$ God $^{\text {Sch }}$ does not exist (from 5 and 6).

A theist can agree with this conclusion and still consistently remain a theist. For the only thing we obtain in the case of the conclusion $(7)^{\text {Sch }}$ is a justification for the claim that there is no such God as Schellenberg constructs Him. ${ }^{39}$

\section{BIBLIOGRAPHY}

Bochenski, Joseph M. The logic of religion. New York: New York University Press, 1965.

DoBRZENIECKI, Marek. Ukrytość i Wcielenie. Teistyczna odpowiedź na argument Johna L. Schellenberga za nieistnieniem Boga. Kraków: WAM, 2020.

DobrZeniecki, Marek. Argument z ukrycia. Obecny stan debaty. Przeglad Filozoficzny 28, no. 1 (2019): 17-32.

Green, Adam, and Eleonore Stump (eds.). Hidden Divinity and Religious Belief: New Perspectives. New York: Cambridge University Press, 2016.

Herbut, Józef. Artykuty i szkice. Z metodologii i teorii metafizyki, filozoficznej analizy języka religii oraz etyki i metaetyki. Opole: Wydział Teologiczny Uniwersytetu Opolskiego, 2008.

Herbut, Józef. “Z syntaktycznej problematyki języka religijnego.” In Józef Herbut, Artykuły i szkice. $Z$ metodologii i teorii metafizyki, filozoficznej analizy języka religii oraz etyki i metaetyki, 239-45. Opole: Wydział Teologiczny Uniwersytetu Opolskiego, 2008.

Howard-Snyder, Daniel, and Paul K. Moser (eds.). Divine Hiddenness. New Essays. Cambridge: Cambridge University Press, 2002.

Mordarski, Ryszard. “Argument z ukrytości Boga Johna L. Schellenberga.” Introduction to Argument z ukrytości. Nowe wyzwanie filozofii dla wiary w Boga, by J. L. Schellenberg. Bydgoszcz: Wydawnictwo Uniwersytetu Kazimierza Wielkiego, 2019.

MRUgALSKI, Damian. “Agnostos Theos: relacja między nieskończonością a niepoznawalnością Boga w doktrynach medioplatoników." Roczniki Filozoficzne 67, no. 3 (2019): 25-51. https://doi.org/ 10.18290/rf.2019.67.3-2.

PePliŃSKI, Marek, and Martyna KoszKalo. "Wszechmoc". In Przewodnik po filozofii religii: nurt analityczny, edited by Janusz Salamon, 37-59. Kraków: WAM, 2016.

PIKE, Nelson. "Divine Omniscience and Voluntary Action." Philosophical Review 74, no. 1 (1965): 27-46. https://doi.org/10.2307/2183529.

PINCKAERS, Servais-Théodore. Les sources de la morale chrétienne. Sa méthode, son contenu, son histoire. 3rd ed. Fribourg: Editions Universitaires, 1993. English translation: The Sources of Christian Ethics. Translated by Mary T. Noble. Washington, DC: Catholic University of America Press, 1995.

${ }^{39}$ I want to thank Dr. Nelly Strehlau and Tomasz Pałkowski for all their remarks that make my text clearer and more readable. 
RoccA, Gregory. "The Distinction between Res Significata and Modus Significandi in Aquinas's Theological Epistemology." The Thomist 55, no. 2 (1991): 173-97.

SChellenberg, J. L. Argument z ukrytości. Nowe wyzwanie filozofii dla wiary w Boga. Translated by Ryszard Mordarski. Bydgoszcz: Wydawnictwo Uniwersytetu Kazimierza Wielkiego, 2019.

Schellenberg, J. L. The Hiddenness Argument: Philosophy's New Challenge to Belief in God. Oxford: Oxford University Press, 2015.

StumP, Eleonore, and Norman KretzMAnN. “Eternity.” Journal of Philosophy 78, no. 8 (1981): 429-58. https://doi.org/10.2307/2026047.

SwInBURne, Richard. The Coherence of Theism. Rev. ed. Oxford: Oxford University Press, 1977.

ВышЕСлАВЦЕВ, Борис. Этика преображенного Эроса. Paris: YMCA Press, 1932.

\section{THE HIDDENNESS ARGUMENT AND THE GROUND OF ITS SOUNDNESS}

\section{S u m m a ry}

The paper refers to the argument from hiddenness as presented in John Schellenberg's book The Hiddenness Argument and the philosophical views expressed there, making this argument understandable. It is argued that conditionals (1) and (2) are not adequately grounded. Schellenberg has not shown that we have the knowledge necessary to accept the premises as true. His justifications referring to relations between people raise doubts. The paper includes an argument that Schellenberg should substantiate its key claim that God has the resources to accommodate the possible consequences of openness to a relationship with finite persons, making them compatible with the flourishing of all concerned and of any relationship that may come to exist between them. At the end of the text, I propose to treat the argument as a rejection of an anthropomorphic God.

Keywords: Hiddenness of God; J. L. Schellenberg; openness of God; perfect love of God; theistic personalism.

\section{ARGUMENT Z UKRYCIA I PODSTAWA JEGO TRAFNOŚCI}

\section{Streszczenie}

Artykuł odwołuje się do argumentu z ukrycia przedstawionego w książce J. L. Schellenberga The Hiddenness Argument i wyrażanych tam poglądów filozoficznych, które stanowią kontekst dla zrozumienia tego argumentu. Twierdzi się tu, że przesłanki (1) i (2) argumentu nie są odpowiednio uzasadnione. Schellenberg nie wykazał, że posiadamy wiedzę niezbędną do uznania tych przesłanek za prawdziwe. Wątpliwości budzą jego uzasadnienia odnoszące się do relacji między ludźmi. Artykuł zawiera argument, że Schellenberg powinien uzasadnić swoje kluczowe twierdzenie, że Bóg dysponuje zasobami, aby pogodzić możliwe konsekwencje otwartości na relację z ograniczonymi osobami, czyniąc je kompatybilnymi z rozkwitem wszystkich zainteresowanych i wszelkich relacji, które mogą zaistnieć między nimi. Na końcu tekstu proponuję potraktować ten argument jako odrzucenie idei antropomorficznego Boga.

Słowa kluczowe: ukrycie Boga; J. L. Schellenberg; otwartość Boga; doskonała miłość Boga; personalizm teistyczny. 